\title{
Necrotizing fasciitis following a motor vehicle accident with Candida species as the sole organisms
}

\author{
Daniel Brian Eisen $\mathrm{MD}^{1}$, Erin Brown MD PhD²
}

\begin{abstract}
DB Eisen, E Brown. Necrotizing fasciitis following a motor vehicle accident with Candida species as the sole organisms. Can J Plast Surg 2004;12(1):43-46.

Necrotizing soft-tissue infections exclusively due to Candida species are rare and not usually considered in the differential diagnosis of this devastating condition. When documented previously, Candida species are generally proposed to be a saprophytic component of multibacterial synergistic infection often associated with streptococcal species. We report a case of a 51-year-old man who developed necrotizing fasciitis secondary to Candida infection following a motor vehicle accident. His clinical presentation was very similar to that of clostridial gas gangrene. The only organisms isolated from tissue culture were Candida albicans and Candida tropicalis. Histopathology confirmed yeast forms and pseudohyphae within the debrided tissue specimens. No bacteria were identified on any of the wound swabs or tissue specimens. Our report is the first that reveals Candida as the sole identifiable cause for necrotizing fasciitis following trauma. Candida should be considered in the differential diagnosis of causative organisms for necrotizing fasciitis and infective myonecrosis.
\end{abstract}

Key Words: Candida albicans; Candida tropicalis; Fournier's gangrene; Myonecrosis; Necrotizing fasciitis; Trauma

\section{Fasciite nécrosante uniquement à Candida après un accident de la route}

\begin{abstract}
Il est rare que les infections nécrosantes affectant les tissus mous soient uniquement dues au genre Candida et l'on ne tient habituellement pas compte de ce dernier au moment d'établir le diagnostic différentiel de cette grave complication. Lorsqu'elle est déjà documentée, la présence du genre Candida est généralement présentée comme un élément saprophyte dans une infection multibactérienne souvent streptococcique. Nous faisons ici état d'un patient de 51 ans qui a développé une fasciite nécrosante secondaire à une infection à Candida après un accident de la route. Le tableau clinique ressemblait fort à celui d'une gangrène gazeuse à Clostridium. Or, les seuls agents pathogènes isolés dans les cultures tissulaires ont été Candida albicans et Candida tropicalis. L'histopathologie a confirmé la présence de levures et de filaments pseudomycéliens dans les spécimens de tissus débridés. Aucune bactérie n'a été identifiée dans les frottis de plaie et les spécimens tissulaires. Notre rapport est le premier à mentionner Candida comme seule cause identifiable de la fasciite nécrosante post-traumatique. Il faut désormais tenir compte de Candida dans le diagnostic différentiel des agents pathogènes incriminés dans la fasciite nécrosante et la myonécrose infectieuse.
\end{abstract}

\begin{abstract}
40-year-old Asian man with no significant past medical A history struck a telephone pole at high speed while driving his automobile. He was belted, and the airbag deployed at impact. The patient was awake at the scene (no known loss of consciousness) and found to be hypotensive (systolic blood pressure of $64 \mathrm{mmHg}$ ). The patient was immediately transferred to the emergency department of a Level I trauma centre.

A focused assessment with sonography for trauma ultrasound was performed and positive for free fluid in the abdominal cavity. A subsequent computed tomography (CT) scan revealed avulsion of the anterior musculature from the iliac crests, a large abdominal hematoma and patchy pulmonary infiltrates of the lower lobes. After completion of the imaging studies, the patient was taken to the operating room for emergent laparotomy. Mesenteric tears were documented, along with fecal soiling of the intraperitoneal area. Portions of the large and small bowel were resected. The patient was then irrigated, and the abdomen closed. No debridement of the devitalized abdominal wall was undertaken. Ciprofloxacin, ampicillin and metronidazole were started to provide
\end{abstract}

prophylaxis against enteric organisms. The patient was then transferred to the intensive care unit for ongoing postoperative care.

Less than $24 \mathrm{~h}$ after leaving the operating room, the patient developed a rapidly progressing, violaceous, indurated, cutaneous eruption on his proximal left anterior thigh and left lower abdomen, with crepitus and subcutaneous emphysema (Figure 1). His temperature was $39.4^{\circ} \mathrm{C}$, and he was hypotensive despite increased volume resuscitation. Intravenous imipenem was started and a CT scan performed. The CT revealed subcutaneous air in an area extending from the distal thigh to the lower abdomen (Figures 2 and 3). Necrotizing fasciitis was suspected and the plastic surgery service was consulted. At the time of evaluation the affected area covered the proximal one-half of the patient's left thigh, the left lower abdomen, the penis and scrotum and the right lower abdominal area.

The patient was taken to the operating room soon after consultation. Wide-spread necrotic areas were found in the fascial plane underlying the affected skin. A finger was easily passed through the fascial plane underlying the discoloured

\footnotetext{
${ }^{1}$ Division of Dermatology, University of British Columbia, Vancouver, British Columbia; ${ }^{2}$ Division of Plastic Surgery, University of British Columbia, Vancouver, British Columbia

Correspondence: Dr Daniel Brian Eisen, University of British Columbia, Division of Dermatology, 835 West 10th Avenue, Vancouver,

British Columbia V5Z 4E8. Telephone 916-997-6346, fax 413-622 9935, e-mail dbeisen@yahoo.com
} 


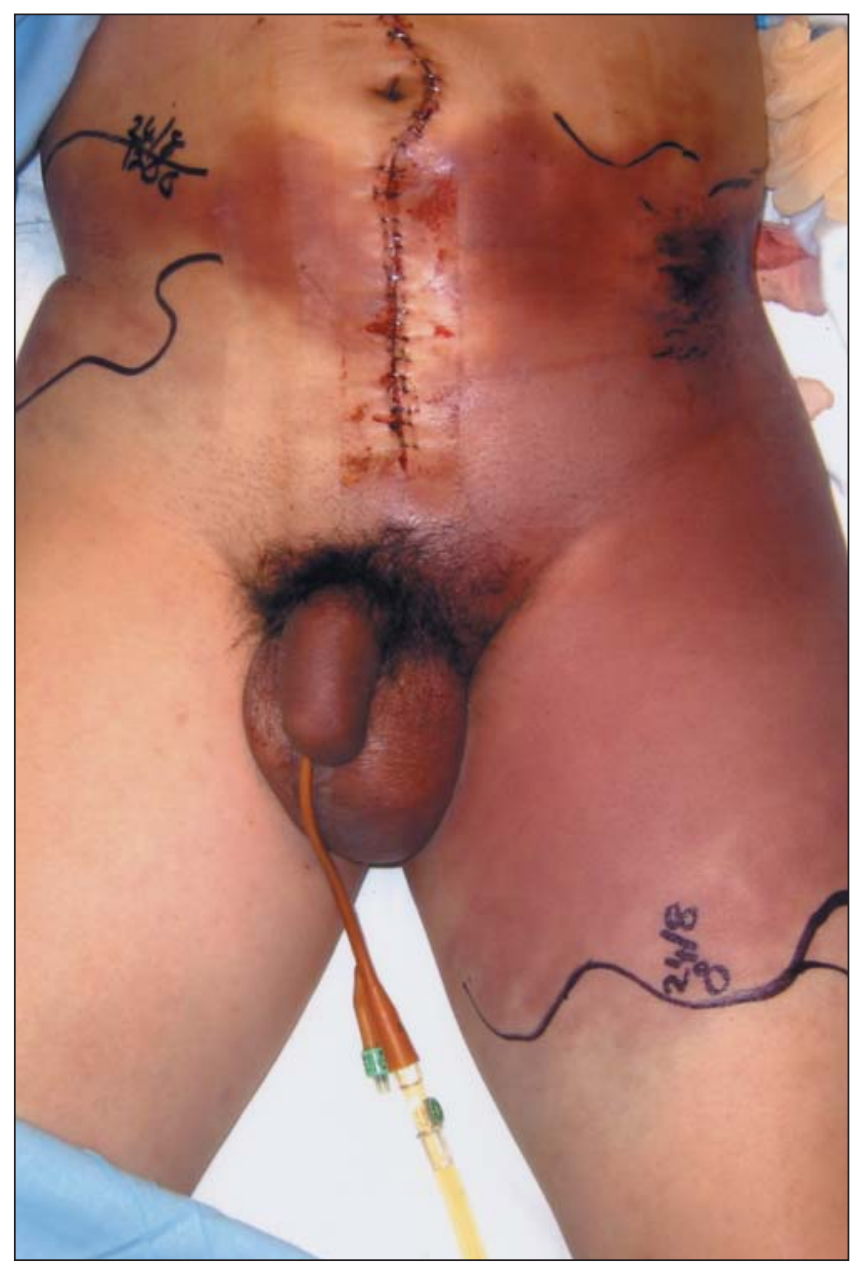

Figure 1) Violaceous skin eruption at time of initial plastic surgery evaluation

skin (positive finger test) (1). The vasculature was thrombosed, and the skin appeared nonviable. Large areas of the avulsed rectus abdominus muscle, internal and external obliques, and transversus abdominus were also found to be necrotic (myonecrosis). The affected tissue was aggressively debrided and several pieces were sent for culture, Gram stain, and histopathological examination. Following debridement, the patient had excision of: the entire inferior portion of the left abdominal wall and overlying skin; a suprafascial portion of the right abdominal skin and subcutaneous tissue; the entire skin envelope of the penis and scrotum; and virtually all of the subcutaneous tissue and skin of the left thigh to the level of the knee.

Gram stains of tissue submitted from the left thigh fascia, and two different sites of affected abdominal wall tissue revealed polymorphonuclearcytes, yeast and pseudohyphae. Histopathology of 13 different skin, muscle, and fascial specimens revealed numerous yeast forms and pseudohyphae contained within areas of necrosis (Figure 4). Bacterial stains were performed and negative for organisms. Intravenous amphoteracin was started. Cultures from one abdominal wall specimen and the left thigh fascia grew Candida albicans. The remaining abdominal wall tissue grew $\mathrm{C}$ albicans and Candida tropicalis. No anaerobes or other bacteria were seen on Gram

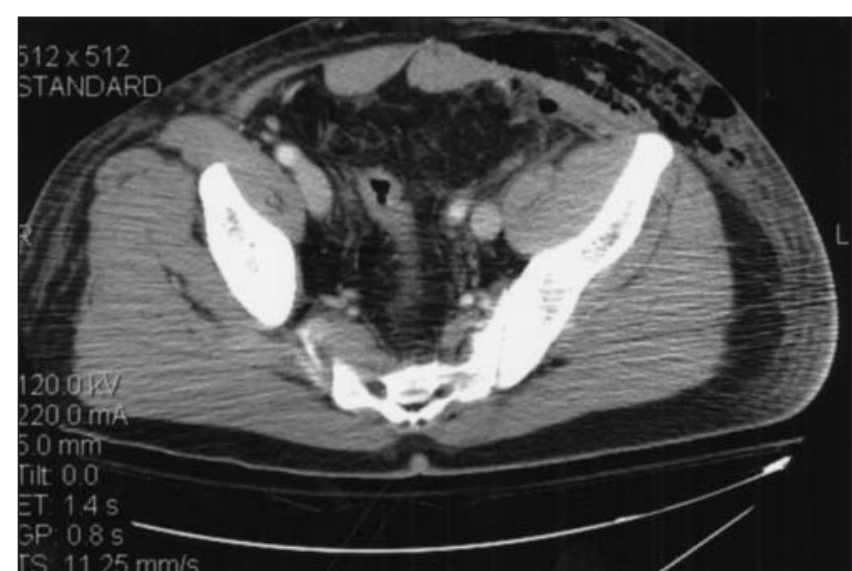

Figure 2) Computed tomography image showing subcutaneous air in abdomen

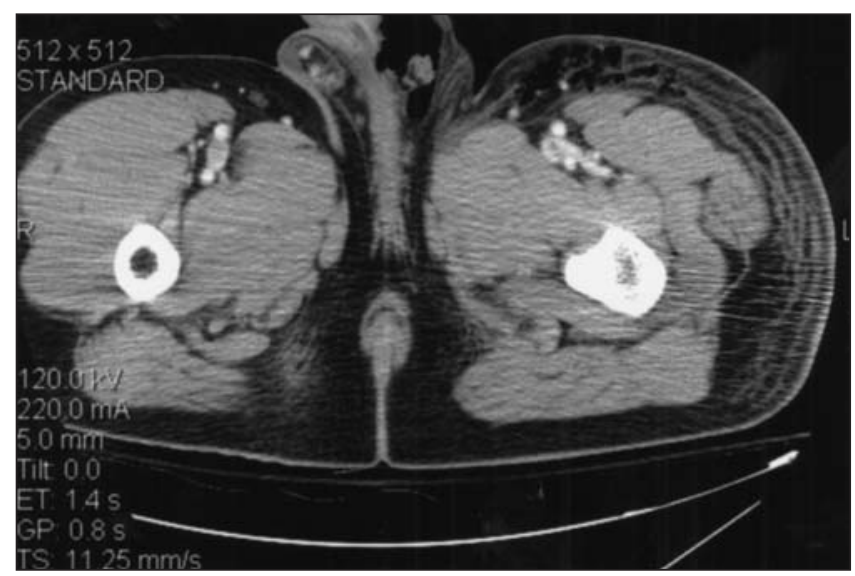

Figure 3) Computed tomography image showing subcutaneous air in proximal left thigh and scrotum

stain or cultured from tissue. Blood and urine cultures were negative.

The patient was started on intravenous fluconazole and his amphoteracin discontinued after culture results ruled out Aspergillus. The patient was returned to the operating room two days later for further abdominal wall resection, loop colostomy, and ileostomy. Specimens submitted to pathology from the abdominal wall revealed numerous fungal elements with the morphology of Candida. Culture results of the tissue again revealed $\mathrm{C}$ albicans. Vicryl mesh was placed over the large abdominal wound, and the remaining graftable wounds were managed with split thickness skin grafts. After several weeks of conservative therapy the patient was weaned off his ventilator and recovered consciousness without any neurological deficits. He has continued to do well and was subsequently discharged home with complete closure of all wounds. He will ultimately require reconstruction of his large left abdominal wall hernia.

\section{DISCUSSION}

Necrotizing fasciitis is a disease with significant morbidity and mortality. Its pathogenesis is not entirely understood. Multibacterial, synergistic infections have been suggested as the cause (2). The disease is thought to be characterized by the 


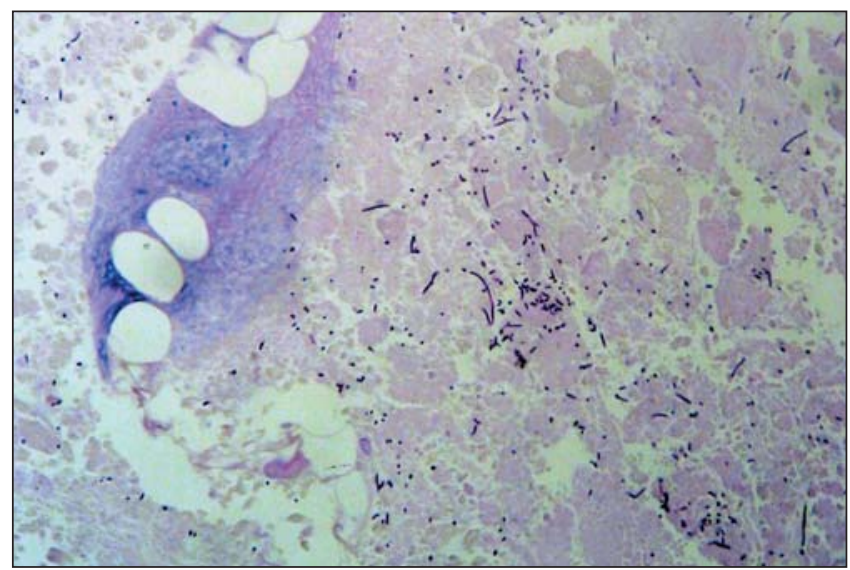

Figure 4) Periodic Acid Schiff stain of debrided tissue showing numerous yeast and hyphal forms

spread of microorganisms along fascial planes, with resulting necrosis of the fascia and overlying subcutaneous tissue (3). If the process continues unabated, a vertical phase may develop whereby the underlying muscle becomes involved. Seventyone per cent of patients with this disease have cultures positive for several types of bacteria, and two-thirds of these include infection with Streptococcal species (4). Necrotizing fasciitis due to fungal organisms is not usual and is rarely reported (5-9). In a retrospective study of 182 patients with necrotizing fasciitis, Candida was isolated in only seven instances (5).

Candida is a well known human pathogen responsible for a wide variety of diseases. It is also known to be a common colonizer of the oropharynx and the intestines in normal individuals $(10,11)$. It is possible that our patient's gastrointestinal tract was colonized by Candida before his accident. The initial surgery or the trauma itself may have allowed Candida to gain access from the contaminated intraperitoneal area to the nonviable abdominal musculature or fascial planes of his abdomen. $\mathrm{C}$ albicans and $\mathrm{C}$ tropicalis are the first and second most common cause of fungemia in humans, respectively (12). The significance of finding $\mathrm{C}$ tropicalis as well as $\mathrm{C}$ albicans on one of the surgical specimens is unknown. Both are invasive organisms and may have both played a role in the fasciitis.

An interesting feature of this case of Candida-induced necrotizing fasciitis was the similarity in presentation to that of clostridial myonecrosis. Clostridial myonecrosis is typically caused by Clostridium perfringens, a commensal usually found in the lower intestinal and female genital tract. It often occurs in the setting of contaminated muscle injury following trauma or bowel and biliary tract surgery. Diagnosis is often based on clinical findings of tachycardia, fever, diaphoresis, extreme anxiety, restlessness, evidence of gas in the tissues, myonecrosis evident at time of surgery and isolation of $\mathrm{C}$ perfringens from blood or tissue (13). Clostridial species release a variety of toxins, which compromise vascular supply to the affected tissue and allow for rapid spread of disease.

Like Clostridial species, Candida is also known to cause disease in which gas production occurs (14-16). The gas is thought to be the byproduct of fermentation. Candida virulence factors important for invasive human infections include adhesins, phospholipases, morphogenic changes, phenotypic switching and secreted aspartyl proteinases $(17,18)$. Adhesins are biomolecules that promote adherence of $\mathrm{C}$ albicans to host cells or host-cell ligands (17). Mutants of C albicans which do not contain these molecules are nonvirulent. Phospholipases are degradative enzymes and the deletion of one of these in an animal model of disease resulted in greatly diminished virulence (18). Morphogenesis refers to the fact that Candida grows both as a single celled yeast form and in a filamentous pseudohyphal and hyphal forms. Often, both yeast and filamentous forms are found in the invaded tissue. It is uncertain whether one form is more pathogenic than the other. In addition to morphogenic changes, Candida has been shown to undergo phenotypic changes resulting from differential gene expression. Certain phenotypes appear to grow better in different host locations and may explain why host immunity to Candida is site specific. Secreted aspartyl proteinases appear to be important in tissue invasion and hyphal growth $(17,18)$.

Mortality rates for necrotizing fasciitis vary from $9 \%$ to $69 \%$ $(19-21)$. The average affected body surface area is $8.4 \%$, with the perineum (Fournier's gangrene) being the most commonly affected site (16). Risk factors for mortality include: age greater than 60 years; elevated lactate dehydrogenase; increasing length of time from admission to debridement; organ failure; comorbid conditions; intravenous drug use; trunk/perineal involvement; and positive blood cultures for B-Streptococcus and bacteremia (4). Predisposing factors for acquiring necrotizing fasciitis include: smoking; intravenous drug use; diabetes; immunosuppression; and peripheral vascular disease (22).

Features important for diagnosis include pain out of proportion to exam in the area with associated skin changes, high fever, tachycardia and hypotension. The affected skin appears differently depending upon what stage the disease is at. Early in the disease the skin is erythematous, sometimes with a few blisters. Late in the course it appears dusky blue with weeping blisters and a border area with surrounding cellulitis (4). Ancillary studies including radiographs or CT scans may be helpful. If there is a lack of certainty regarding diagnosis a small incision may be made with local anesthesia. If a finger passes easily through the fascial plane (positive finger test) then this is an indication of disease. In addition, rapid frozen sections may be performed to confirm the diagnosis histologically (1).

The most important and urgent treatment for this disease is aggressive surgical debridement of all the affected tissues. Inadequate excision or delays to treatment increase mortality $(22,23)$. Other forms of treatment include broad spectrum antibiotics, wound care and nutritional supplementation. Hyperbaric oxygen has been used on a number of occasions with some success, but randomized, controlled studies are lacking. Any therapy should be considered as an adjunct to surgery and not a substitute or reason to delay it.

\section{CONCLUSION}

Our case provides compelling evidence for Candida as a primary pathogen in this case of necrotizing fasciitis. Several specimens of tissue grew Candida species and pseudohyphae were seen on both Gram stain and histopathological analysis of the affected tissue. No bacteria were isolated from the patient's tissue during the initial onset of the disease or seen on gram stain or histopatholgy. Our report is the first that reveals Candida as a cause for necrotizing fasciitis following trauma, in a similar pattern to that seen in clostridial myonecrosis. Candida should be considered as a cause in the differential diagnosis of necrotizing fasciitis and clostridial gas gangrene. 


\section{REFERENCES}

1. Stamenkovic I, Lew D. Early recognition of potentially fatal necrotizing fasciitis: The use of frozen-section biopsy. N Engl J Med 198;310:1690-3.

2. McHenry CR, Piotrowski JJ, Petinic D, Malongoni MA. Determinants of mortality for necrotizing soft-tissue infections. Ann Surg 1995;21:558-63.

3. Rea WJ, Wyrick WJ. Necrotizing fasciitis. Ann Surg 1970;172:957-64.

4. Childers BJ, Potyondy LD, Nachriener R, et al. Necrotising fasciitis: A fourteen-year retrospective study of 163 consecutive patients. Am Surg 2002;68:109-16.

5. Elliott D, Kufera JA, Myers RAM. The microbiology of necrotizing soft tissue infections. Am J Surg 2000;179:361.

6. Kazuyoshi J, Nakatoh M, Kadowaki T, Kushima M, Koizumi S, Okada Y. Fournier's gangrene caused by Candida species as the primary organism. Urology 2000;56:153-4.

7. Johnson MA, Lyle G, Hanly M, Yeh KA. Aspergillus: A rare primary organism in soft-tissue infections. Am Surg 1998;64:122-6.

8. Mathews MS, Raman A, Nair A. Nosocomial zygomycotic postsurgical necrotizing fasciitis in a healthy adult by Apophysomyces elegans in south India. J Med Vet Mycol 1997;35:61-3.

9. Takaba H, Okamura K, Tanaka J, Kato K, Shimonji T. Fournier's gangrene: A case report. Kinyokika Kiyo 1987;33:1285-8.

10. Fotos PG, Lilly JP. Clinical management of oral and perioral candidiosis. Dermatol Clin 1996;14:273-80.

11. Lacour M, Zunder T, Huber R, Sander A, Daschner F, Frank U. The pathogenetic significance of intestinal Candida colonization A systematic review from an interdisciplinary and environmental medical point of view. Int J Hyg Environ Health 2002;205:257-68.

12. Hazen K. New and emerging yeast pathogens. Clin Microbiol Rev 1995;4:462-78.
13. Garcia-Suarez J, de Miguel D, Krsnik I, Barr-Ali M, Hernanz N, Burgaleta C. Spontaneous gas gangrene in malignant lymphoma: An underreported complication? Am J Hematol 2002;70:145-8

14. Wise GJ. Fungal infections of the urinary tract. In: Walsh PC, Retik AB, Stamey TA, et al, eds. Campbell's Urology, 6th edn. Philadelphia: WB Saunders, 1992:928-50.

15. Humayun H, Maliwan N. Emphysematous genital infection caused by Candida albicans. J Urol 1982;128:1049-50.

16. Paty R, Smith AD. Gangrene and Fournier's gangrene. Urol Clin North Am 1992;19:149-62.

17. Calderone R, Fonzi W. Virulence factors of Candida albicans. Trends Microbiol 2001;7:327-34.

18. Niewerth M, Korting C. Phospholipases of Candida albicans. Mycoses 2000;44:361-7.

19. Fustes-Morales A, Gutierrez-Castrellon P, Duran-Mckinster C, Orozco-Covarrubias L, Tamayo-Sanchez L, Ruiz-Maldonado R. Necrotizing fasciitis: Report of 39 pediatric cases. Arch Dermatol 2002;138:893-9.

20. Wagner JD, Prevel CD, Elluru R. Histoplasma capsulatum necrotizing myofasciitis of the upper extremeity. Ann Plast Surg $1996 ; 36: 330$.

21. Korhonen K. Hyperbaric oxygen therapy in acute necrotizing infections. With a special reference to the effects on tissue gas tensions. Ann Chir Gynaecol 2000;89(Suppl 214):7-36.

22. Sudarsky LA, Laschinger JC, Coppa GF, Spencer FC. Improved results from a standardized approach in treating patients with necrotizing fasciitis. Ann Surg 1987;206:661-5.

23. Wang K, Chun-Hsiung S. Necrotizing fasciitis of the extremities. J Trauma 192;32:179-82. 